Cornell University Law School Scholarship@Cornell Law: A Digital Repository

$3-2015$

\title{
Education Rights and Wrongs: Publicly Funded Vouchers, State Constitutions, and Education Death Spirals
}

Michael Heise

Cornell Law School, michael.heise@cornell.edu

Follow this and additional works at: https://scholarship.law.cornell.edu/facpub

Part of the Education Law Commons

\section{Recommended Citation}

Michael Heise, "Education Rights and Wrongs: Publicly Funded Vouchers, State Constitutions, and Education Death Spirals," 42 Fordham Urban Law Journal 745 (2015)

This Article is brought to you for free and open access by the Faculty Scholarship at Scholarship@Cornell Law: A Digital Repository. It has been accepted for inclusion in Cornell Law Faculty Publications by an authorized administrator of Scholarship@Cornell Law: A Digital Repository. For more information, please contact jmp8@cornell.edu. 


\title{
EDUCATION RIGHTS AND WRONGS: PUBLICLY FUNDED VOUCHERS, STATE CONSTITUTIONS, AND EDUCATION DEATH SPIRALS
}

\author{
Michael Heise* \\ A response to Julie F. Mead, The Right to an Education or the \\ Right to Shop for Schooling: Examining Voucher Programs in \\ Relation to State Constitutional Guarantees, 42 FORDHAM URB. L.J. \\ 703 (2015).
}

\section{TABLE OF CONTENTS}

Introduction .745

I. What to Infer from Increasingly Popular Voucher Programs? ...748

II. Reframing the Relation Between Constitutional Obligations and Vouchers .752

A. Alternative Ways to Frame Publicly Funded Voucher Programs .753

B. Money as a Partial Solution for Struggling Public Schools .756

III. Adverse Selection and Death Spirals: The NCLB, ACA, and School Voucher Opposition

Conclusion

\section{INTRODUCTION}

Professor Julie Mead's Article considers whether publicly funded voucher programs "subvert" states' ability to provide an "adequate" public education consistent with state constitutional requirements. ${ }^{1}$

* Professor, Cornell Law School.

1. Julie F. Mead, The Right to an Education or the Right to Shop for Schooling: Examining Voucher Programs in Relation to State Constitutional Guarantees, 42 FORDHAM URB. L.J. 703 (2015). 
The critical analytic move in Mead's Article involves characterizing publicly funded voucher programs as a "discretionary option" and, in contrast, a state's duty to adequately fund traditional public schools as a state constitutional "obligation." " Mead then argues that the growth in the number of publicly funded voucher programs and the accelerating participation rates in those programs threaten to dilute states' abilities to meet their constitutional obligations owed to traditional public schools. ${ }^{3}$ Paradoxically, then, it is the interaction of voucher programs' increased popularity and states' increased willingness to fund them that Mead exploits to support her conclusion that "[s]tate constitutions have clearly established that children have a genuine right to a quality public education, not merely the privilege to shop for schooling in the educational marketplace."4

Just to be clear-and this central point bears repetition-Mead's argument seeks to transform voucher programs' increased popularity, and state governments' increased willingness to fund them, into reasons to limit voucher programs rather than expand them. Or, a more modest form of Mead's thesis is that regardless of what happens to voucher programs, struggling traditional public schools need more, rather than less funding that results partly from a diminishing share of students served by traditional public schools.

Perhaps even more important than Mead's argument itself, however, is that the structure of her argument implies an overly constrained understanding of publicly funded vouchers and their relation to a student's right to an adequate education. That is, Mead's argument understands publicly funded vouchers through the lens of only those children who attend public schools (as well as public schools' numerous institutional interests and constituencies, including teacher unions).

Of course, other lenses exist and publicly funded voucher programs are capable of far more nuanced and granular understandings than Mead's Article emphasizes. For example, one alternative way to understand publicly funded voucher programs is to consider how they provide some-perhaps many-students with their only meaningful access to an adequate education. This is certainly the case for far too many students, many of whom are students of color or from lowincome households, or both, and assigned to "failing" or 
"inadequate" public schools. ${ }^{5}$ Finally, efforts to limit school choice, particularly in today's No Child Left Behind Act of 2001 (NCLB) ${ }^{6}$ motivated intensive standardized test environment, imply an awareness of adverse selection, a core insurance law doctrine. ${ }^{7}$ And partly in an effort to ward off more "educational death spirals," those defending public schools, such as Professor Mead, seek to limit alternative educational options and diminish the ability to exit failing (or successful) public schools. The desired background goal-to dampen the increasing number of public schools lurching towards an "educational death spiral"-however, will continue to confront substantial headwinds. Unlike, for example, the individual mandate provision in the Affordable Care Act (ACA), ${ }^{8}$ which is singularly essential to what the ACA seeks to accomplish as an insurance instrument, a similar "individual mandate" is simply not constitutionally possible in the education context.

Thus, even if the core argument in Mead's Article succeeded and public financial support for voucher programs diminished, such an outcome would only indirectly assist the struggling public schools Mead seeks to aid. ${ }^{9}$ On the one hand, it is certainly plausible that public schools would receive increased funding (funding otherwise committed to voucher programs). On the other hand, however, while reducing one exit option from struggling public schools, it would not eliminate other exit options..$^{10}$ To the extent that struggling public

5. See generally Richard D. Kahlenberg, All Together Now: Creating Middle-Class Schools Through Public School Choice 25-28 (2001); James E. Ryan, Schools, Race, and Money, 109 YALE L.J. 249 (1999).

6. No Child Left Behind Act of 2001, Pub. L. No. 107-110, 115 Stat. 1425 (2002) (codified as amended in scattered sections of 20 U.S.C.).

7. In the insurance law context, adverse selection "typically refers to the (theoretical) tendency for high-risk people to be more interested in insurance than low-risk people are." THOMAS BAKER \& KYlE D. LOgue, InSURANCE LAW AND PolicY: CASES AND MATERIAls 12 (3d ed. 2013). See generally Tom Baker, Containing the Promise of Insurance: Adverse Selection and Risk Classification, in RISK AND MORAliTy (Richard Ericson \& Aaron Doyle eds., 2003). In the education context, adverse selection involves the tendency for high-achieving students to seek high-performing schools.

8. Patient Protection and Affordable Care Act, Pub. L. No. 111-148, 124 Stat. 119 (2010), amended by the Health Care and Education Reconciliation Act of 2010, Pub. L. No. 111-152, 124 Stat. 1029 (codified as amended in scattered sections of 20, 26, and 42 U.S.C. (2012)).

9. See Mead, supra note 1, at 736-38.

10. That is, parents with the financial ability to do so may still elect for their children to exit public schools in favor of private schools. Moreover, the increasing popularity of public charter schools provides another exit option from struggling public schools. See infra note 18. 
schools need not only more funding, as Mead implies, ${ }^{11}$ but also to attract and retain the very types of students inclined and motivated to exit struggling public schools, reducing public support for voucher programs will only reduce, but not eliminate, avenues to exit failing public schools. Moreover, reducing access to voucher programs as an exit option will also disproportionately harm students from lowincome households and exacerbate differences between public and private school profiles. ${ }^{12}$ While the Constitution permits states to compel education, it does not permit states to compel (or "mandate") public-only education. ${ }^{13}$ Consequently, adverse selection will persist as a threat to public schools unable to deliver satisfactory education services.

\section{WHAT TO INFER FROM INCREASINGLY POPULAR VOUCHER PROGRAMS?}

Professor Mead's Article nicely inventories the surprising recent growth of publicly funded voucher programs as well as various "voucher-like" programs. ${ }^{14}$ In Table 1 , Mead rightly emphasizes that twenty states now have some form of a publicly funded voucher program and "fifteen programs have been enacted since just 2013."15 This recent surge will not surprise families participating in voucher programs. It will surprise few, if any, to learn that the survey data from those participating in voucher programs convey genuine enthusiasm. ${ }^{16}$ Of course, self-selection assuredly explains much of these results, as one would expect to detect enthusiasm for voucher programs from those who willingly chose to participate in them.

11. See Mead, supra note 1 , at 736 .

12. Without access to publicly funded voucher programs, fewer children from low-income households will benefit from the opportunity to attend private schools. One consequence is that the absolute and relative percentage of low-income students attending private schools will drop.

13. See Pierce v. Soc'y of the Sisters of the Holy Names of Jesus \& Mary, 268 U.S. $510(1925)$

14. See Mead, supra note 1 , at 707 .

15. See id.

16. See, e.g., Janet R. Beales \& Maureen Wahl, Private Vouchers in Milwaukee: The PAVE Program, in Private Vouchers 57-59 (Terry M. Moe ed., 1995) (providing data on participating parental support of the Milwaukee program); see also Michael Heise et al., Private Vouchers in Indianapolis: The Golden Rule Program, in PRIVATE VOUCHERs, supra, at 113 (providing data on participating parental support of the Indianapolis program). 
More telling, perhaps, is the more generalized increased demand for greater education options. ${ }^{17}$

Notwithstanding participants' unsurprising enthusiasm for school voucher programs, the spike in the growth of the publicly funded voucher programs that Mead describes will likely surprise many, particularly when assessed in light of the even more pronounced and sustained growth of charter schools during the past decades. ${ }^{18}$ One source of surprise flows from the sustained, persistent, and important forces that act against publicly funded voucher programs. Public school teacher unions supply one predictable, vocal, and powerful source of opposition to publicly funded voucher programs. ${ }^{19}$ Indeed, the nation's two leading teacher unions, the National Education Association and the American Federation of Teachers, benefit from "vast resources, huge memberships, pervasive political clout, and by almost any estimate are among the most powerful interest groups in all of American politics." ${ }^{20}$ That teacher unions typically-and enthusiastically-oppose publicly funded voucher programs will surprise few. Non-public schools pose an important threat to union membership and parochial union interests to the extent that these schools and their growth threaten to redirect public resources away from public schools and toward private schools. Thus, teacher union opposition to voucher programs is both obvious and well-understood.

17. See, e.g., Dominick DiRocco, Note, Making the Grade: School Choice Comes to New Jersey, 22 Seton Hall LeGIS. J. 281, 283 (1997) (observing that "public demand for school choice is at an all time high in the United States"). Consistent, stable data on general public support for voucher programs, however, are more elusive. See Terry M. Moe, Schools, Vouchers, And THE American Public 25255 (2001). More recent studies have provided additional data in this area of study. See, e.g., William G. Howell et al., The Public Weighs in on School Reform, Educ. NEXT, Fall 2011, at 11, 16-19.

18. From 1999-2000 to 2011-2012, the percentage of all public schools that were public charter schools increased from $1.7 \%$ to $5.8 \%$, and the total number of public charter schools increased from 1500 to 5700. As well, charter schools have generally increased in enrollment size over time. From 1999-2000 to 2011-2012, the number of students enrolled in public charter schools increased from 0.3 million to 2.1 million students. During these same years, the percentage of public school students who attended charter schools increased from $0.7 \%$ to $4.2 \%$. Finally, from 2010-2011 to 2011-2012, the number of students enrolled in public charter schools increased from 1.8 million to 2.1 million. See Fast Facts: Charter Schools, NAT'L CENTER FOR Educ. STATS., http://nces.ed.gov/fastfacts/display.asp?id=30 (last visited Feb. 26, 2015).

19. See, e.g., Jonathan P. Krisbergh, Marginalizing Organized Educators: The Effect of School Choice and 'No Child Left Behind' On Teacher Unions, 8 U. PA. J. LAB. \& EMP. L. 1025, 1034-36 (2006) (describing teacher unions as among school voucher programs most vocal critics).

20. See MoE, supra note 17, at 2. 
Yet other factors also fuel opposition to publicly funded voucher programs. One such factor involves the public's overall satisfaction with public schools. As Professor Terry Moe notes, public opinion data, at least through the year 2000, tends to suggest that on average Americans are "fairly satisfied" with public education. ${ }^{21}$ Even if the American public opinion was somehow mistaken, many Americans are financially incented towards satisfaction with public schools. After all, in many suburban contexts, particularly suburbs that benefit from high-performing public schools, home prices reflect the perceived (and real) efficacy of the local public schools. ${ }^{22}$ Thus, if nothing else, suburban homeowners possess an important economic incentive that tilts them toward satisfaction with their local public schools and, as well, against public support for private schools that might compete against their public schools.

Ambivalence or antipathy towards publicly funded voucher programs, whatever its source or sources, is not confined to abstractions and is evidenced in concrete ways. For example, forces working against publicly funded school voucher programs have coalesced and fueled significant and persistent political losses for school voucher proposals placed on ballots. ${ }^{23}$ It would be easy, indeed too easy, to ascribe voucher programs' ballot initiative losses to teacher union political opposition alone. To be sure, teacher unions are among voucher programs' most vocal and organized critics. But responsibility for voucher proposals' political losses is more accurately shared by a convergence of allied interests. Among the less-appreciated opponents of voucher programs is suburban opposition, especially suburbs that benefit from well-functioning and desirable public schools. ${ }^{24}$

Thus, the publicly funded voucher programs' recent and notable legislative success that Mead documents ${ }^{25}$ becomes far more notable

21. See MoE, supra note 17 , at 70.

22. See, e.g., James E. Ryan \& Michael Heise, The Political Economy of School Choice, 111 Yale L.J. 2043, 2081 (2002); David D. Troutt, Ghettoes Revisited: Antimarkets, Consumption, and Empowerment, 66 BRoOK. L. REV. 1, 10 (2000) (noting that "[t]he reputation of the schools, in turn, adds to the value of their homes"); see also Thomas W. Hazlett, Selected Skirmishes: Class Warfare, REAsON (Feb. 1, 1997), http://reason.com/archives/1997/02/01/class-warfare/print (calling this "the ugly financial story lurking behind the soccer-mom pandering on education").

23. See Mead, supra note 1 , at 705. An interesting puzzle emerges, however, when one compares voucher programs' lack of success on ballot initiatives with their growing legislatives successes. Id.

24. For an extended discussion of this point, see generally Ryan \& Heise, supra note 22 .

25. See Mead, supra note 1, at 708 tbl.1. 
when this growth is nested into a general political context noted for indifference, at best, toward voucher programs. The politics that surround voucher programs continue to shift, and they are shifting in directions more amenable to voucher proponents. That is to say, what is notable about the voucher program growth that Mead's Article documents is that it exists, notwithstanding considerable and sustained political hostility. ${ }^{26}$

What can one reasonably infer from the recent growth in public support (and public financial support) for voucher programs that the Mead Article documents? Clearly, any such growth is both relatively recent and, candidly, quite modest. ${ }^{27}$ As such, any inferences should be similarly modest. If nothing else, recent developments imply that the political context surrounding the school voucher debate is evolving, and the velocity of change is increasing. That the political impulse for publicly funded voucher programs frequently stems from concerns for students-and their families-otherwise trapped in struggling public schools remains particularly telling. ${ }^{28}$ Moreover, one of the NCLB's palpable legacies, discussed more fully below, involves an educational climate increasingly dominated by standardized testing. ${ }^{29}$ While reasonable minds can, and do, differ on the substantive policy merits of increased standardized testing, such testing, combined with affirmative annual reporting requirements, has made the performance of schools far more transparent and accessible to parents. $^{30}$ Making objective and salient information about school (and student) performance more accessible and transparent

26. Mead echoes the widely acknowledged fact that "publicly funded private school voucher programs have not fared well when placed on ballots ...." Id. at 705.

27. For example, while the Supreme Court concluded in 2002 that publicly funded voucher programs did not necessarily violate the Establishment Clause in Zelman $v$. Simmons-Harris, 536 U.S. 639, 639 (2002), Professor Mead identified only twentyfour states that have enacted some form of a publicly funded voucher, or voucherlike, program since then. See Mead, supra note 1, at 707, 708 tbl.1.

28. See, e.g., Clint Bolick, Voucher WARs: Waging the Legal BAtTle over ScHOOL CHOICE 15-43 (2003) (describing Polly Williams' efforts to lead a school voucher campaign in Milwaukee, Wisconsin).

29. See, e.g., Marc Pilotin, Finding a Common Yardstick: Implementing a National Student Assessment and School Accountability Plan Through State-Federal Collaboration, 98 CALIF. L. REV. 545, 545 (2010) (noting that "[s]tandardized testing permeates American public education").

30. Compare Diane Ravitch, Get Congress Out of the Classroom, N.Y. TIMEs, Oct. 3, 2007, at A25 (noting that NCLB "has unleashed an unhealthy obsession with standardized testing"), with Thomas F. Risberg, Note, National Standards and Tests: The Worst Solution to America's Educational Problems... Except for All the Others, 79 GEO. WASH. L. REV. 890 (2011) (arguing that national standards and assessments is the least bad policy option). 
contributes to increased parental demands for greater control over their children's educational futures. ${ }^{31}$ An increase in parental demands for control over their children's schools has fueled an increase in political demands for greater access to private education markets and schools. ${ }^{32}$ Thus, at the very least, one plausible inference from the growth in publicly funded voucher programs that Mead's Article illustrates is that the public demand for more access to private schools is both increasing and becoming increasingly successful politically.

\section{REFRAMING THE RELATION BETWEEN CONSTITUTIONAL OBLIGATIONS AND VOUCHERS}

Professor Mead's Article construes publicly funded vouchers as a threat to adequate public education, partly because of the resulting diversion of resources away from public and toward private schools. ${ }^{33}$ The main threat to "regular" public schools-funding-comes into sharper relief when one accounts for practical fiscal realities. Specifically, Mead's Article identifies the greater absolute and relative share of public education funds now going to voucherrecipient schools that otherwise (presumably) would have gone to public schools. This allocation jeopardizes the public schools' ability to discharge their duty to provide students with "adequate" educational services. ${ }^{34}$ Having argued that publicly funded voucher programs threaten public schools' ability to deliver a stateconstitutionally required "adequate" education, Mead goes on to conclude that where such a threat exists, state constitutions must preference public school funding over funding for voucher programs. $^{35}$

The central move in Mead's Article-asserting that state constitutions in general, and their education clauses in particular, preference adequate public schools over publicly funded voucher programs - warrants attention for conceptual and empirical reasons. First, as a conceptual matter, Mead's move implies a narrow and one-

31. See, e.g., Mike Johnston, From Regulation to Results: Shifting American Education from Inputs to Outcomes, 30 YALE L. \& POL'Y REV. 195, 196 (noting how NCLB empowered parents in part by increasing transparency of student academic performance).

32. See, e.g., Howell et al., supra note 17, at 16 fig.4, 17-19.

33. See, e.g., Mead, supra note 1, at 737 (noting that data "suggests that future challenges to [publicly funded] voucher, tax credit scholarship programs, and education savings account programs may take the form of school finance litigation").

34. Id. at 739.

35. Id. 
dimensional understanding of the relation between voucher programs and state constitutional guarantees for an adequate education. By framing the understanding in the manner that she does, Professor Mead ignores the possibility that publicly funded voucher programs may provide some students with their only meaningful access to an adequate education. ${ }^{36}$ And this would be particularly true for those children assigned to struggling traditional public schools. ${ }^{37}$ Second, as an empirical matter, it does not necessarily follow that "inadequate" public schools will become "adequate" solely with the infusion of additional funds. To some (admittedly unknown) degree, such factors as, for example, student peer effects, also contribute to a schools' efficacy and student academic achievement outcomes independent of funding levels. ${ }^{38}$ And, to the extent that non-funding variables contribute to school adequacy, Mead's Article does not fully account for them and their potential influence.

\section{A. Alternative Ways to Frame Publicly Funded Voucher Programs}

Mead's Article frames the relation between voucher programs and state constitutional guarantees for adequate education in only one direction. Specifically, Mead understands voucher programs as generating a threat to or impeding public schools' ability to deliver a state constitutionally required adequate education. ${ }^{39}$ Voucher programs' relation to adequate educational guarantees, however, is far more complex and nuanced than Mead's Article suggests. Indeed, one can just as easily and plausibly understand voucher programs as a policy instrument that can increase-not decrease-access to adequate education. And this alternative way to understand voucher programs is especially apt for sub-groups of students not presently well-served by public schools.

To illustrate this point, let us adopt, for example, the perspective of a student who, through no fault or choice of her own, finds herself born into a low-income household that lacks the full array of

36. Indeed, to take but one example, Ohio initiated a publicly funded voucher program for the city of Cleveland, as the Supreme Court noted in Zelman $v$. Simmons-Harris, to provide "educational assistance to poor children in a demonstrably failing public school system ...." 536 U.S. 639, 640 (2002).

37. $C f$. $i d$. (noting that Ohio enacted its voucher program to educationally assist poor children in demonstrably failing public school systems).

38. For a brief summary of the related technical literature, see Richard D. Kahlenberg, Learning from James Coleman, PUB. INT., Summer 2001, at 54.

39. See Mead, supra note 1, at 736-38. 
educational assets typically (but by no means exclusively) found in middle- and upper-income households and neighborhoods. Let us further assume that this low-income student resides at a specific address served by a local public school previously adjudicated by the state's supreme court as (state) constitutionally "inadequate." To bring this thought experiment fully within the scope of the issues raised by the Mead Article, let us also assume that a fully accredited, academically thriving, private (and tuition-charging) school operates across the street from the student's struggling and "inadequate" public school. That our hypothetical student is legally entitled to discharge her state required compulsory education obligations by attending the private school is uncontested, as the Supreme Court in Pierce $v$. Society of Sisters makes this option unambiguously clear. ${ }^{40}$ Exercising her "Pierce option," however, requires a degree of disposable income that this student's family simply cannot afford. Thus, as our student cannot attend the private school absent a publicly funded voucher program, she finds herself legally compelled to attend an inadequate public school.

Sadly, indeed, tragically, the scenario described above is not merely an academic thought experiment. The "scenario" is reality for far too many students across the United States. From the perspective of this student-and the many other students who live this reality every day - a publicly funded voucher program serves as an education "life boat" and a literal, concrete means to access a quality education. Given her family's limited financial means, a publicly funded voucher program is functionally the only way she can exit a failing or inadequate public school that she is otherwise legally required to attend. Thus, such voucher programs can contribute to a net increase in the number of students served by adequate schools. What Mead characterizes as an "extra educational expenditure," understood as "extra" for those students who need public subsidies to access successful private schools. Thus, for financially needy students, particularly those relegated to failing public schools, publicly funded voucher programs can help ensure that they receive something approximating equal educational opportunity.

Even more perplexing is that Mead's Article understands the threat posed by publicly funded voucher programs from the perspective of public schools and public school districts, noting, as did the Ohio Supreme Court, that publicly funded voucher programs,

40. See Pierce v. Soc'y of the Sisters of the Holy Names of Jesus \& Mary, 268 U.S. 510, 534-35 (1925).

41. Mead, supra note 1 , at 736 (emphasis in original). 
"should not come at the expense of our public education system or our public school teachers.",42 Even if voucher programs diluted public education school funding, positive rights to an adequate education enshrined in state constitutions or education clauses attach to individual students - not a "public school system," ${ }^{43}$ public school teachers, or administrators. Indeed, in typical school finance (or "adequacy") litigation, public schools and districts are among those named as defendants, not plaintiffs. While reasonable minds canand frequently do $^{44}$-differ on just what is meant by an "adequate" education, it simply cannot be understood as - or reduced to-a jobs protection act for the benefit of public school teacher unions.

For the sake of argument, however, let us grant Mead's conclusion that states must first "adequately" fund their public schools before committing public funds to voucher programs and then consider likely consequences. ${ }^{45}$ One immediate consequence, of course, is that our hypothetical student described above would lose access to a thriving private school and, instead, be legally obligated to attend an "inadequate" public school. But what would not happen is equally important and instructive. Specifically, as Mead correctly acknowledges, students benefitting from households that can afford private school tuition still retain their ability to exit failing public schools for more desirable private schools. ${ }^{46}$ Thus, while Mead's conclusion will result in fewer people exiting public for private schools, it will only do so for students whose families lack the resources to pay for private school tuition absent a state subsidy. Some student cohorts, notably middle- and upper-income students, as well as motivated students able to secure alternative ways to finance private school education, will retain their ability to exit public schools. Paradoxically, such students may possess important human capital that public schools, especially struggling public schools, seek to attract and retain. ${ }^{47}$ Such students, however, remain outside of the reach of Mead's conclusion.

42. Id. at 728 (quoting Simmons-Harris v. Goff, 711 N.E.2d 203, 212 (Ohio 1999)).

43. See id. at 737, 739-40.

44. See, e.g., Joshua E. Weishart, Transcending Equality Versus Adequacy, 66 STAN. L. REV. 477, 477 (2014) (noting that debates about "equal" or "adequate" education have persisted for decades).

45. See Mead, supra note 1, at 737-38.

46. See id. at 743 (stating "[i]t is certainly true that parents may not be compelled to enroll their children in public schools").

47. See generally Christopher Lubienski \& Peter Weitzel, Choice, Integration, and Educational Opportunity: Evidence on Competitive Incentives for Student Sorting in Charter Schools, 12 J. GENDER RACE \& JUST. 351, 352-53 (2009) (noting 


\section{B. Money as a Partial Solution for Struggling Public Schools}

Even if the concerns expressed in Mead's Article about the deleterious fiscal consequences to public schools posed by publicly funded voucher programs are correct, such concerns are incomplete, as they do not adequately reflect the rich array of non-fiscal variables frequently associated with desired student academic outcomes. As a full review of decades of sophisticated, technical, and empirical literature resides beyond the scope of this Essay, what follows endeavors only to quickly describe the basic contours of this literature.

While for many policymakers involved in education reform efforts the ultimate barometer of success or failure is student academic achievement, precisely what causes some students to perform well and others less well remains hotly debated and not well understood. ${ }^{48}$ Thus far, a loose consensus lands on the importance of peer effects on student academic achievement and social behavior. ${ }^{49}$ While there is emerging agreement that good teachers, strong principals, small schools, small class sizes, and parental involvement can improve student achievement, the significance of these variables and their complex interactions remain contested. ${ }^{50}$ Added to these specific areas of debate is the more general and lingering dispute over the extent to which expenditures correlate with achievement-that is, over whether money "matters" in the school context and, if so, how might it matter. ${ }^{51}$

how the "mix" of social characteristics in a school can influence key outcomes, including student achievement).

48. For a recent discussion, see, for example, Wendy Parker, The Failings of Education Reform and the Promise of Integration, 90 TEX. L. REV. 395, 408-09 (2011) (reviewing James E. Ryan, Five Miles AwAy, A World APART: One City, Two Schools, and THE STORY OF EDUCATIONAL OpPORTUNITY IN MODERN AMERICA (2010)).

49. James Coleman was the first to report this, in his famous 1966 study for the (now) Department of Education, which has since become known simply as "The Coleman Report." James S. Coleman ET AL., EQuality OF EduCATiOnal OPPORTUNITY (1966) (studying student achievement and finding stronger correlation between student achievement and nonschool factors than between achievement and school factors). Scores of subsequent studies have confirmed Coleman's conclusion. For citations to the literature, see KAHLENBERG, supra note 5, at 25-28; Ryan, supra note 5 , at 286-87, nn.165-66.

50. See Ryan \& Heise, supra note 22, at 2102-03; see also KAHLENBERG, supra note 5 , at $36-37$.

51. For research generally skeptical of a correlation between educational spending and educational achievement, see ERIC A. HANUSHEK ET AL., MAKING SCHOOLS WORK: IMPROVING PERFORMANCE AND CONTROLLING COSTS 25-48 (1994); Allan R. Odden \& Lawrence O. Picus, School Finance: A Policy Perspective 
Setting aside such long-standing debates, what is reasonably clear is that something as complex as student academic achievement almost assuredly does not pivot on any single variable, such as school funding in general or marginal school funding diverted to private schools through publicly funded voucher programs in particular. ${ }^{52}$ Equally clear is that schools with a high concentration of students from lowincome households rarely, if ever, perform as well as their middleclass counterparts. ${ }^{53}$ This generally holds true even when substantial resources are provided to these schools. ${ }^{54}$ Although several reasons explain why this might be so, one key point is the clear and undisputed one that, for an array of complex reasons, schools noted for concentrations of student poverty rarely realize their potential. ${ }^{55}$ Thus, while policymakers' focus on school funding is hardly inapt, a belief that funding levels alone can influence academic achievement ignores the rich complexity of variables that inform student academic achievement.

\section{AdVERSE SELECTION AND DEATH SPIRALS: THE NCLB, ACA, AND SCHOOL VOUCHER OPPOSITION}

One standard critique advanced against school voucher programs, publicly or privately funded, is that they risk "skimming" away from public and towards private schools those students comparatively better-positioned and motivated for academic success. ${ }^{56}$ At its core, the "skimming" argument contains two critical components and

277-81 (Lane Akers ed., 1992); Eric A. Hanushek, The Impact of Differential Expenditures on School Performance, Educ. Researcher, May 1989, at 45, 48-50. For research generally supportive of such a correlation, see Ronald F. Ferguson, Paying for Public Education: New Evidence on How and Why Money Matters, 28 HARV. J. On LegIS. 465, 483-90 (1991); Larry V. Hedges et al., Does Money Matter? A Meta-Analysis of Studies of the Effects of Differential School Inputs on Student Outcomes, EDUC. ReSEARCHER, Apr. 2014, at 5, 13.

52. See generally KAHLENBERG, supra note 5, at 36-37 (discussing factors that studies have shown are more closely linked to student achievement than increased school spending).

53. For a fuller account of this point, see Ryan \& Heise, supra note 22, at 2103-08.

54. See id. at 2106-08; see also Michael Heise, Litigated Learning, Law's Limits, and Urban School Reform Challenges, 85 N.C. L. REv. 1419, 1447-53 (2007) (noting that a shift from school finance litigation strategy from equity to adequacy reflected, in part, that per pupil spending in many under-performing urban schools exceeded state per pupil spending means).

55. See Ryan \& Heise, supra note 22, at 2103-08.

56. See, e.g., James Forman, Jr., Do Charter Schools Threaten Public Education? Emerging Evidence from Fifteen Years of a Quasi-Market for Schooling, 2007 U. ILL. L. REV. 839, 855 (2007) (voicing concerns over skimming effects resulting from school choice policies). 
pivots on a doctrine, adverse selection, which is central to, among other enterprises, insurance markets. First, public school advocates typically complain that voucher programs drain public schools of some of their highest-achieving and most motivated students (and their households). ${ }^{57}$ What is frequently left unstated in polite, public conversation, yet logically necessarily follows, is the implication that those students "left behind" in public schools disproportionately include students who are comparatively less academically competitive or motivated or those who are more difficult (and expensive) to educate. ${ }^{58}$ This is particularly bothersome to public schools now that public and private schools increasingly compete for students.

A second related, though distinct, component-flowing from the first - is that the steady departure of a public school's comparatively more motivated students may fundamentally alter a school's internal dynamics in two potentially important (and damaging) ways consistent with what adverse selection would predict. First, the departure of a school's most able and motivated student cohort may prompt that school's next most able and motivated cohort to leave as well. $^{59}$ And so on. Second, if so, at some point the increasing diminution of an absolute and relative number of able and motivated students itself will transform a school's academic culture, climate, and political clout in less than desirable ways. ${ }^{60}$ A degradation of a school's academic culture or climate might launch a school into an education "death spiral" and hasten a "race to the bottom." ${ }^{61}$ Once ignited, education death-spirals are difficult to arrest and reverse, as they feed on their own self-generated destructive centripetal forces. ${ }^{62}$

Once again, for the sake of argument, let us simply assume the plausibility of the threat posed by adverse selection critique exacerbated by publicly funded school voucher programs. Whatever the adverse consequences to public schools may have been in the past, the implementation of NCLB dramatically increased them. To help accomplish its many statutory goals, NCLB requires states to

57. See, e.g., id. at 840 .

58. See id. at 840, 851-56. This point is also discussed by Professor Mead. See Mead, supra note 1, at 740-41.

59. See generally Forman, supra note 56.

60. See id. at 840.

61. For an early discussion of how adverse selection can trigger a "death-spiral" in insurance markets, see, for example, David M. Cutler \& Richard J. Zeckhauser, Adverse Selection in Health Insurance, 1 F. FOR HEALTH ECON. \& POL'Y 1, 8 (1998).

62. See generally id, Peter W. Cookson, Jr., School Choice: The Struggle FOR THE SOUL OF AMERICAN EDUCATION 91-93 (1994); Ryan \& Heise, supra note 22, at 2092. 
develop and self-impose challenging academic standards, ${ }^{63}$ annually test students to assess progress toward state standards, ${ }^{64}$ and gather and disseminate relevant information to parents and others. ${ }^{65} \mathrm{~A}$ requirement that schools must demonstrate adequate yearly progress or face increasingly onerous sanctions resides at the heart of NCLB. ${ }^{66}$ As a consequence, while a greater number of students and, ideally, a greater number of academically proficient students were traditionally deemed an asset to public school districts, the possibility of adverse consequences from NCLB flowing from not enough students demonstrating "adequate" academic progress made attracting - and retaining-proficient students an even higher priority for public school districts. ${ }^{67}$

Insurance markets understand well the almost existential threat posed by adverse selection and how it can trigger "death spirals." ${ }^{\circ 8}$ Indeed, at the heart of the insurance market enterprise are tasks risk-pooling and rating-designed to blunt the ill-effects of adverse selection. $^{69}$ Indeed, those who helped draft President Obama's signature health insurance legislation, the ACA, understood this point better than most. Those who crafted the ACA's structural design understood well the essential need to compel, under force of law, participation in the health insurance pools through the individual

63. See No Child Left Behind Act of 2001, 20 U.S.C. § 6301(1) (2012).

64. See id. $\S 6311(\mathrm{~b})(2)(\mathrm{G})$.

65. See id. § 6311(h); see also Michael Heise, Courting Trouble: Litigation, High Stakes Testing, and Education Policy, 42 IND. L. REV. 327, 330-31 (2009) (discussing the NCLB requirements).

66. See 20 U.S.C. $\$ \S 6316(b)(5),(8)$ (2012).

67. See generally id, James E. Ryan, The Perverse Incentives of the No Child Left Behind Act, 79 N.Y.U. L. REV. 932 (2004).

68. A balanced risk pool is necessary for insurance instruments to work. In the health insurance context, for example, a health insurance company's enrollment must contain a balance of relatively healthy (less costly) and unhealthy (more costly) individuals. A risk pool dominated by unhealthy enrollees will exert upward pressure on premium costs. Increasing premium costs, however, will induce the marginally healthier enrollees to exit and seek a less costly health insurance policy. The departure of the marginally healthier enrollees fuels even more premium price increases and, again, more departures of the marginally healthier enrollees. Such a "death spiral," once triggered, is self-propelled. See, e.g., Ronen Avraham et al., Understanding Insurance Antidiscrimination Laws, 87 S. Cal. L. Rev. 195, 204-05 n.28 (2014); Peter Siegelman, Adverse Selection in Insurance Markets: An Exaggerated Threat, 113 YALE L.J. 1223, 1224 (2004). For a discussion of the "death spiral" potential in the ACA context, see, for example, Mark A. Hall, Evaluating the Affordable Care Act: The Eye of the Beholder, 51 Hous. L. REV. 1029, 1039 (2014).

69. See BAKER \& LOGUE, supra note 7. 
mandate to help generate the necessary heterogeneous risk pool. ${ }^{70} \mathrm{~A}$ heterogeneous risk pool was - and remains - a fundamental necessity to insure that enough premium-paying healthy participants would be able to cross-subsidize their less-healthy counterparts now that health insurance companies' ability to define and manage risk pools was limited by the ACA..$^{71}$ Indeed, wholly independent of one's views of the constitutional integrity of the Supreme Court's recent decision to uphold the constitutionality of the ACA's individual mandate provision in National Federation of Independent Business $v$. Sebelius, ${ }^{72}$ few-if any-observers seriously contested the empirical proposition that without the individual mandate the ACA would structurally implode. ${ }^{73}$

While individual mandates may be able to compel participation in health insurance markets within the ACA context, such mandates are clearly not possible in the education context. To be more precise, while compulsory education laws across the states are, of course, certainly permissible, as Pierce made clear, what Pierce also made crystal clear is that states may not compel public education. ${ }^{74}$ That is, families remain free to discharge their affirmative educational obligations through public or private schools. And even if states could compel public-only education, states cannot mandate where people live, and the Court's decision in Milliken v. Bradley illustrates judicial deference to school district boundaries. ${ }^{75}$ Thus, the interactive effect of the Pierce and Milliken decisions all but

70. See Patient Protection and Affordable Care Act, 26 U.S.C. § 5000A (2012) (the "individual mandate"). For a discussion of why the individual mandate is essential to address critical adverse selection problems, see Abigail R. Moncrieff, Cost-Benefit Federalism: Reconciling Collective Action Federalism and Libertarian Federalism in the Obamacare Litigation and Beyond, 38 AM. J.L. \& MED. 288 (2012).

71. See, e.g., 42 U.S.C. $\$ \S 300 g g-1,300 g g-4$ (2012) (prohibiting health insurance companies from denying coverage due to an applicant's pre-existing conditions); 42 U.S.C. $\$ 300 g g-14$ (2012) (requiring health insurance companies to provide coverage for young adults on their parents' policies through age twenty six); see also Rebecca E. Zietlow, Democratic Constitutionalism and the Affordable Care Act, 72 OHIO ST. L.J. 1367 (2011).

72. See Nat'l Fed'n of Indep. Bus. v. Sebelius, 132 S. Ct. 2566 (2012).

73. See, e.g., Tonja Jacobi, Obamacare as a Window on Judicial Strategy, 80 TENN. L. REV. 763, 812 (2013) ("[N]o one disputed that the very reason for the ACA's individual mandate was to make the broader legislation work without bankrupting the insurance companies...."); see also Sebelius, 132 S. Ct. at 2625 (Ginsburg, J., concurring in part, concurring in the judgment in part, and dissenting in part) (quoting Gonzales v. Raich, 545 U.S. 1, 37 (2005) (Scalia, J., concurring)).

74. See Pierce v. Soc'y of the Sisters of the Holy Names of Jesus \& Mary, 268 U.S. 510, 534-35 (1925).

75. See Milliken v. Bradley, 418 U.S. 717 (1974). 
precludes the government's ability to mandate public school attendance in the same manner the federal government now mandates participation in health insurance markets.

Thus, while faltering public schools-similar to insurance markets - are exposed to adverse selection risks, and NCLB sanctions enhance the consequences to faltering public schools, neither public school administrators nor government officials possess the legal authority to prevent children from departing struggling public schools (at least those who benefit from the ability to depart struggling public schools for other schools). Consequently, the adverse selection threat to struggling public schools is both real in theory and obvious in reality.

Public school advocates, including Professor Mead, appear increasingly sensitive to the adverse consequences, deepened by NCLB, that flow from a family's right to exit struggling schools, even though such flight may exacerbate a public school's struggles. Lacking the constitutional ability to blunt adverse selection's illeffects on public schools by mandating that families enroll their children in public schools, public school advocates turn to efforts to reduce access to the private school market. $^{76}$ One such effort, reflected in the Mead Article, is to reduce public financial support for voucher programs. ${ }^{77}$ Of course, those children lucky enough to be born into wealthy families are all but immune from such reductions and retain the ability to exit private for public schools.

\section{CONCLUSION}

Professor Mead's Article casts helpful and important light on the unexpected recent growth in publicly funded voucher programs. Given the political opposition such programs reflexively stimulate, the recent surge in legislative support warrants note. That such programs appear to be gaining political popularity illustrates not only the ever-shifting politics surrounding education policy, but also the public's growing frustration with the inability of too many public schools to generate and deliver adequate education services.

76. Arguments, such as the one advanced by Professor Mead, that seek to preference the interests of public schools over those of students and their parents who seek greater access to private school through publicly funded voucher programs, illustrate this impulse.

77. Indeed, Mead argues that publicly funded voucher programs are proper only after "adequate financial resources are first directed to the public schools." Mead, supra note 1 , at 737 . 
Efforts to enlist the growing popularity of publicly funded voucher programs into the service of arguments to reduce public support for voucher programs, such as Mead's, strike me as unpersuasive. The core of Mead's Article reflects an unduly narrow conception of the relation between voucher programs and educational adequacy, to say nothing of aspirations for greater equal educational opportunity. Mead's argument also privileges the parochial self-interests of public schools and public school teachers over the interests of children and families seeking greater education options. Finally, to the extent that efforts to reduce available education options reflects growing concerns about adverse selection's consequences for public schools, Mead's argument falls short. Unlike in the health insurance context, where federal law can compel citizen participation in health insurance markets, no such similar legal instrument exists in the education context. While Mead's argument indirectly seeks to reduce flight from failing public schools, it cannot eliminate flight from public schools by those families fortunate enough to have the ability to exercise school choice without a public subsidy.

Years ago I wrote that while social science remains unable to explain why too many schoolchildren do not achieve desired academic performance levels, the failures themselves are hauntingly easy to predict. $^{78}$ Sadly-even tragically-what Professor Howard Gardner observed in 2000 remains in full force today: "Tell me the ZIP code of a child and I will predict her chances of college completion and probable income; add the elements of family support (parental, grandparental, ethnic and religious values) and a few degrees of freedom remain, at least in our country."79

That Professor Gardner's alarming observation exists-let alone persists-should trouble anyone who seeks to plausibly harbor a belief in America's ideal of equal educational opportunity. To the extent that equal educational opportunity means anything, it must at the very least mean that ZIP codes should not predict a child's educational destiny. As such, education policy makers should seek policies that contribute to and expand, rather than impede or limit, avenues toward greater equality of educational opportunity.

78. See Michael Heise, Choosing Equal Educational Opportunity: School Reform, Law, and Public Policy, 68 UnIV. CHI. L. REV. 1113, 1136 (2001). 49.

79. Howard Gardner, Paroxysms of Choice, N.Y. REV. Books, Oct. 19, 2000, at 